\title{
The Labor Concept of Marx, Calvin, Luther in the Framework of Legal or Religious Rights
}

\author{
Dr. Ago Silvana \\ Europian University of Tirana \\ silvanafilozofi@yahoo.com
}

\begin{abstract}
:
The most recent studies on economic ethics of world religions try to remind us once again the link between religion and economics in social rights, as one of the most important links of social stratification. The desire and passion to approach the idea of the man, who wants to live with both the matter and the spiritual, brings us to rethink once again that man needs a new social and religious spirit at the same time. As a scholar of religion and morality Weber shows the relation between religion, labor, and the right. It can never be left out without clarifying the problem that we are inspired by a new course "the opportunity to own" what we want. One can never abandon the idea that inspiration coming from religion brings a new level - a profession, which basically makes you who you are as a professional. We try to understand a new situation that basically is less complicated "intuition". No matter how much we want to be pure in what we see in intuition, it isn't clear in religion. Maybe the obstacle that the religion wants to present to intuition is much stronger than that. "The intuition" regarding the human being seems to be an intuition, to be grasped through your own intelligence, whereas the intuition comprehended as religion, through new ways brings a more complicated situation than this. - It brings us a situation when one choice makes you lose control. The narrowing of these two gaps which are seen both with the right to work as well as the right to have a new inspiration under the order of labor, leads to the desire to see Marx, Calvin and Luther as the Reformers of the rule of social relationships under the right of religious morality.
\end{abstract}

Keywords: work, moral, religion, ethics, economics.

\section{1 The "Spirit of Capitalism" concept according to Karl Marx.}

A new perspective, seen from a different angle is that of Marx. The Marxist idea is somehow tougher and more radical, but the confrontation of religion makes you understand that at the core of both sides stands the capitalistic ambition. The idea Marx gives to economic and social life is a completely separated concept from religion, as long as we see the social life incorporated in a new perspective of a new philosophy. This is what Marx calls "the work of proletariat". ( K. Marx, 1974)

At least in the frame of what Webber brings to us, we understand that our attitude is a new one, at the core of it is the development of a new society, which strips off the man from unexplainable religious fears, and places him in the legal rights of free choice. The inspiration that gives us faith in the rationality makes us be more rational regarding our choices and less irrational regarding our thoughts. The observation of thought, which seems not to lead us where we want to, is a new effort of thought that creates what we call the Spirit of Capitalism.

The capitalist of Marx is a person who gets satisfied with his work and his main goal is the development of an economy in his favor. Here is Marx understanding of society: "Such are the rules that act as priority - they are the rules of a society, which has at its foundation a private economy, whereas the posteriori rules are the ones that derive from capitalists.

"[ K. Marx 1974, 66]. To give an explanation to what we have understood from Marx and review from my personal perspective, a relation somehow analogue of a new understanding of the society, is the concept of labor by Marx which now is not on an individual term but on a collective one. Marx in analyzing the western world makes us understand once again that the society we live in is the society that offers a new unification - a world at the centre of it is the profit without 
considering the struggle and hard working laborers. So, what the western world sees as an opportunity, has at its core the development of a life, which views more the spirit of capitalism than the laborer's life.

One can see that the stream that Marx shows is a stream which places at the centre of development a world without religion and ideology. This is what he writes in his comments, "the mechanism of commune tells us that where there is division of labor based on a plan, a natural law acts that shows the division of roles and is created naturally by individuals only" [K, Marx 1974]. The discussion brings to our attention that the development of a society is the development of an environment which makes us understand and emphasize that all mechanisms or as Marx calls them "manufactures" K. Marx 1974 ]" are created by the man in his interest. The man has created his life in a way to be organized but also to bring enjoyment. - At least this is what Marxism portrays, different from Protestantism that has luck as a concept. Luther and Erasmus connect profit and the development of man and his profession as related to luck, such a thing does not happen in capitalism.

Marx at least, based on an aspect or theory he had for labor, under the action of a new development - a development that depends on the fate determined by the capitalist. There is harsh criticism if the fate of a man belonging to protestant religion is also determined by a supernatural force or God. On the other hand for Marx it is completely the opposite. He links the development only to a new belief - one that comes only from the work of the individuals. The fate or luck is connected to the work we do for ourselves and the service we contribute to society.

Marx in his concept of rigorous division of labor saw also the progress of division of roles that brings individuality. Our understanding is that creation is the proof of the individuals "the product of my work is a part of me". [The editor Fabbio 1996, pg 130]. The individuality that our work brings, our creation it nothing but a new job, a labor that will bring a new aid, which in itself will free us once again from the suffocating thought that is commanded by nonexistence.

The social practice that Marx shows us in this part of his work comes as a result of what we perceive as a duty, that in the core has a phenomenon of our work, the one we inherit and the one that has in itself purification. A subversion or overturn of the two social nuances implying capitalism and socialism are further defined by the purity of being an individual seeking to be differentiated from his work. Unquestionably it is important to discuss the social working class that is certainly part of the automation change. The automation work according to the concept of what he calls the "MACHINERY" is not nothing but an alienation. The crossing we do over Marx is more of a move that takes us away from morality. The work is seen as an occupation where the man in a social group does not alienate himself and fights for the greater good, not only for him, but also for the social group. The individual dealing with others is an individual who understands what it means to produce and to be detached from ideologies that are obstacles, mainly the religion. (K. Marx 1974 there).

Atheism according to Marx is a characteristic of the progressive class and the English and French materialists were the ideologists of the bourgeois class that was progressing. Immediately after the bourgeois came into power, the differences between the proletariat and bourgeois grew bigger and degraded. The bourgeois class abandoned the freedom of thought and turned to religion in order to make masses in a dormant state. [Editori, Fabbio 1996, pg 133] Marxism revealed the essence of religion, by exposing that religion is nothing but a fanatic reflection in people's heads - those outer heads that rule them on a daily basis. Maybe by coincidence my mind went to the laws of Solon who created an imaginary God in order to rule his people. Or said in a fun way, the silly things we tell our children at home about witches and ogres in order to have control over them. According to what I understand from Marx's interpretation, it is clear his understanding that religion is a lie used for those who we want to oppress - of course the approach is remarkable because it oppresses the whole society, not just a part of it.

In the German Ideology manuscripts "Communism Journal"(1965) and the manifesto of communist party consider religion as one of the states of social conscience and one of the elements of the superstructure within social classes. It was discovered that religion depends on the development of social relations, class structure of social classes that have an interest in religion to be kept as a tool to act and restrain the masses. They argued that Christianity was born as a result of people's mentality that had reached a level of desperation due to the brutally suppressed bloodshed of slaves and the poor that led to their rebellion including the oppressed nations that were against the ruling of Roman Empire.

There is no doubt that this argument is being treated on a completely opposite perspective. Reforms saw that the need for a clean capitalist spirit is the need of the society, which in itself has a new understanding - an understanding that strips you 
off from new arguments - from outwards arguments. In the heart of what is needed for the economy as a whole, is an economy without religious dogmas.

\section{2. Luther's Conception of the Calling (Vocation). Task of the Investigation.}

Both the German word "Beruf" and the English word "calling" have a religious connotation of a task set by God. The more we emphasize the actual case of the words the more it becomes recent. The longer we research through Christianity the more we understand that Catholics often connect that connotation calling or vocation = task. [Weber, Max Tiranë. 2005, pg 89] The reason we bring this introduction is to recall in our judgment how important is for protestants the calling or to be exact the task. The judgment of Luther at first was a judgment coming due to an obligation by Christianity as a result of commandments of the church. As a result, it would undertake other functions as well.

The word "beruf" took a second meaning which was that of apprenticeship. According to Luther this concept will be considered as a purpose of profit. Even though in his religious language it meant to love religiously, and do good deeds, Luther's idea is clear from the point that he is aware of what this element of occupation has in its foundation. Even though in the beginning he has not spoken for a proper "beruf" that serves Christ and the divine good. Nevertheless, one thing seen in all these efforts of Luther is to place moral on a higher position. The task is seen as something that is followed and becomes a rule of the morality and as such it helps the individual to have morality in his task. We remember Cant as being influenced by Luther and the word 'beruf" exactly how they have the same approach towards it, as a task led under the influence of morality.

So the word "beruf" expresses that central dogma of all protestant streams, which throws away the distinction from Catholics and the ethical commandments of Catholicism "praecepta"and "Consiglia"W, Max, Tiranë2005 same there].

In order to explain those practices we would say that they have existed earlier on, and having in mind the time of use we see that religion is used as an occupation as well. The narrowing of the meaning of these two words came under the theory of reformation, but Catholicism connected the task only with the service to God.

The concept of Luther mentioned above develops and becomes an individual occupation desired from God. This was a natural necessary basis of the existence of religious faith, but morally it was neutral as eating and drinking. We no longer live in the past when the lifestyle of monks was working with no profit and no money, where the greatest satisfaction was found in reading the gospel and the commandments. The concept and analysis that Luther gives is quite similar with that of our modern world. We live in a world with an anthropological and scientific basis, but in essence and thought, mind and spirit with faith in God.

We understand and clarify the sense we bring one that is really the essence of a task, a moral launched by the desire not to be passive. In fact there is no doubt that this assessment in moral of life in occupation is nothing but a rating that essentially has brought in what is called a secular development of the Reformation of the free initiative of the task initiated by the moral.

However there is no need to go into these details because the occupational concept in religious state was somehow different in the judgment of religion. Luther thought that this particular occupation of the individual becomes even more of a special commandment of God's Will. He often linked the occupation/profession with fate, considering the way he was educated based on tradition, it would not clarify the individual. (Luther \& Calvin Dita 2000 Tirana, pg 127). Luther. Even before renaissance, it was believed often that man was not the master of his own destiny but it is someone else that decides his fate. Even Luther shared this opinion. Perhaps occupation or frankly the choice of the occupation was the result of fate or destiny. Eventually this given fate would please him because God had chosen it.

This belief sometimes shows unconditional obedience to the given situation, so, the concept that Luther gave about occupation was coming as a result of fate, and had simply only one traditional concept. So, to my understanding he did say much about the man had no power, no choice but to obey to his destiny. This sentiment also rejects the other idea that occupational work is a duty or obligation, or rather it is the duty imposed by God. The thought of this secularism is not yet detached from the idea of determining a fate that ultimately comes from what we call destiny or fate. (Roterodami. Erasmi. Tiranë. 2004). 
Destiny is created by a supreme someone superior to us, super-natural creature that is God. It is the God that Luther called as the most dignifying leader in every step of our lives.

A proper attitude towards occupation was that of Jesus himself. This is also proper in the arguments it brings regarding work as a necessity. Let's see what he says: "give us this day our daily bread". [W. Max, Tiranë, 2005] We know that religion in the first place brings within the moral spirit of each of us, the human coexistence. Of course, our life does not need to be fed only by morality but wanting to be guided by the possibility of survival strategies. The calling of God in the Old Testament does not examine the work as a whole. St. Paul himself does not see in us the work, but he makes an eschatological call to provide all the services that we are lacking.

Luther seems to have read the Bible through the eyes of his spiritual state, but what he tried to assure us, was harder than that, it was the essence of the existence of each of us. The opportunity to be placed in a new occupation is an occupation that can ensure us a better life. Luther was very clear in his opinion that although social life was short, it was a life that in its foundation had the opportunity of satisfaction.

Luther unquestionably saw occupation as a manifesto of what the LORD has said. We have said before that the Reformation was not separated at all from this part. What society thought of it as a whole was that it is a society that is still run by the morality of religion and only religion could help it to move forward.

Luther's concept of occupation is unquestionably the concept of entirely traditional occupation. One must accept fully his fate and to be entirely faithful to his work that comes from the fate that Lord has given. [lbid Max Weber 2005]. His traditional explanation is clear as long as the moral of one is about God. The man in no way has to feel isolated from God. By no means we go outside this framework thinking that the exit from the Middle Ages will bring individual work. However, the idea that Luther is trying to tell us is pure and clear over a morality that everyone has in order to exist, over the obligation to respect the duty as it comes from morality doing the right thing, not acting on an impulse.

\section{3 Calvin's concept on Occupation.}

Analyzing these two philosophers is required a different effort from Lutheranism. The way they define working concepts is somehow different from the one that reformation has. Having in mind that the thought for the human is clearer, even the working concept was clearer than the one of Lutheranism. At least Erasmus of Rotterdam treats a clearer thought for man as a human being. Addressing of humanism that Erasmus unfolds is in itself a confrontation with his desire to be an individual.

In his scripts he clarifies that the individual knows very well his concept of work, and his high expectations in what he is looking for. Thinking that the task is related to morality is a very interesting part of it. . To him morality of course is not a religious aspect, but is about the love that we have with one another rather then that the love have for others.

The explanation that deals in this discussion of the morality of his madness is that the duty is a feeling that streams as a form of needin each of us. To move onto the concept of work that other reformers have explained we can mention Calvin (Timothy. F. Lull Usa, 1989, pg 154). According to Calvin, what we want is actually a lot more from what we have. It is known and clear that the assessment given by Calvin is a nature which revolves in faith. Luther and Calvin linked the task with destiny - a destiny that is led and inspired by a new opportunity of religious development.

Luther and Calvin express themselves in this way: "The meaning of our destiny is filled with the dark mysteries which to seek and to discover would be bumptious " [Weber Max Tirana 2005]. We understand that even this philosopher has not yet clarified the idea where to find the question of fate and how simple we have to discover an occupation for ourselves. Faith in religion or in the Lord has made us seeing even ourselves as a portent of fate. The social activity of a Christian is just work "In majorem glorial Dei = for glory of the great Lord. So, this character is carried from the work for an occupation which serves the earthly life of the community. [ibid] Christianity connects everything with dedication to God. Even to Luther this part seems to be a bit strange, but in itself is a work which can be done with the love we have for God.

Regarding Luther we say that the origin of the specialized work was seen as connected "to the love for the others". But the thing that needs to be emphasized is that it remained a constructive stitch. To Calvinist it became a stitch of the character 
of their ethical system. The love for the other is believed to be only for the service and the glory of God, not for the glorification of creatures as Calvin called it. He first expressed the realization of the occupation giving by Lex naturalis (law of nature) and in this process such thing takes a special character, objective and not on a personal level. [Calvin, Jane Chichago 1958, 319] Lex naturalis could not be understood differently other than something that the composition of occupation did not bring productivy.

The service we seek to give to religion is something very different from what we seek to do to the man. To Calvinists it is very important that something that could have been personal was something that had to be done in the name of religion and as such required dedication to God. Calvin has a quality that seems to be similar to his contemporary Erasmus of Rotterdam - human and individual character. This character does not seek for a minute to separate itself from God, but on the contrary is very much connected to Him.

The source of individual character of Calvinist ethics is found in the rationalism, which from it derived general features of Calvinist concept on the occupation. The book which treats this part, before doing so, a very important part was taken into consideration that he calls pre-destiny. What he really wants to say with the word pre-destiny we will clarify below.

To Calvin himself that was not an issue. What in fact was the issue was the sense of safety that the person should feel in that what he asked for. The question that we often ask ourselves is: Do we feel safe in our abilities and do we have the needed knowledge to earn an occupation to be in line with our ethics. Regarding this answer, Calvin said it was enough to get to know God's idea and to be led by His education - only in this way we can decide for ourselves.

It is interesting even in this passage what Calvin emphasizes that God chooses people in His work. The physical appearance in no way shows us anything and gives us nothing, but what we need is the faith that God gives to those people. The realization of the work is the one that makes the difference between the chosen and not chosen ones. The main important thing for Calvin is that he saw the occupation as services. He even thought that the occupation of pastors or priests were a service of an occupation that was chosen by God.

\section{Conclusions}

The development of social and economical life has always gone through the religious life. What Marx wants to emphasize is that work and free fair traid comes only from the capitalist life.

The idea of reformers for the social life of the modern society goes through the right to believe and understand the attitude not only to God, but on the right of each one to free labor. This is the reason that this scrip seeks to build the right of each one to be part of it.

Reformation of course supports the idea that religion is completely different from what we have known from books. The man only through his work knows God and the freedom to be part of the legal society. The freedom to choose, even the work is one that pushed the man to be what he is now- a citizen that makes sure his product does no remain dull.

What could be called the foundation of Marx's critique, Calvin's and Luther's is that the man makes religion and not religion makes the man. The religion is the conscience of the man and self-sensitivity of the man, who has not found himself or not lost it again. The man is not an abstract being that shelters himself outside the world. State and society is the man - this state, this society creates religion. Religion is the general theory of this world. It transforms the human being in a fanatic reality because the human being does not have a real reality. So the war against religion is the war against that world that in reality is religion itself.

To give the final conclusions we give importance on the critiques and analysis of the three reformers stating that people create religion and not religion creates the people. 


\section{Bibliography :}

Calvin, Jean"Calvin Commentaries"Library of congress Card. Chicago 1985

Editori. Fabio. "I Klassici del penisero" Milano: 1996

Luteri\&Calvini"Mbi autoritetinshekullar dhe qeverisjen civile"ISP\&DITA2000. Tiranë

Marx. Karl "Kapitali". Tiranë : 1974

Roterdamit. I. Erazmus "Lavdërimi i marrëzisë " ISND. Tiranë 2004

Weber. Max "Etika protestante dhe shpirti i kapitalizmi" Plejad. Tiranë: 2005

Timothy. F. Lull. "Martin Luther's basic theological" USA 1989. 